\title{
Descriptions of four new Mexican riodinids (Lepidoptera: Riodinidae)
}

\author{
CURTIS J. CALLAGHAN ${ }^{1}$, JORGE LLORENTE-BOUSQUETS ${ }^{2,3} \&$ ARMANDO LUIS-MARTINEZ $^{2}$ \\ ${ }^{1}$ Av. Boyacá, Cra. 72 No 129-01, Bogotá, Colombia. E-mail: curtiscallaghan@yahoo.com \\ ${ }^{2}$ Museo de Zoología, Facultad de Ciencias, UNAM Apdo. Postal 70-399. México 04510 D. F. MÉXICO. \\ E-mail: jlb@hp.fciencias.unam.mx \\ ${ }^{3}$ Corresponding author
}

\begin{abstract}
Four new riodinid taxa from Mexico are described as follows: Euselasia pontasis sp. nov., Euselasia aurantiacus aurum ssp. nov., Exoplisia azuleja sp. nov., Synargis nymphidioides septentrionalis ssp. nov. The status of Necyria larunda Godman \& Salvin, 1885, is reviewed. Habitats and distributional ranges are described for each taxon.
\end{abstract}

Key words: Panama, Central America, genitalia, systematics, butterflies, biogeography

\section{Resumen}

Se describen cuatro taxones nuevos de riodínidos mexicanos como sigue: Euselasia pontasis sp. nov., Euselasia aurantiacus aurum ssp. nov., Exoplisia azuleja sp. nov., Synargis nymphidioides septentrionalis ssp. nov. También se revisa el status taxonómico de Necyria larunda Godman \& Salvin, 1885. Para cada taxón se gráfica su distribución y se describe su hábitat.

\section{Introduction}

The Lepidoptera fauna of Mexico has long been celebrated for its diversity and high rates of endemism (Llorente-Bousquets \& Luis-Martínez, 1993; Luis-Martínez et al., 2003). Although the country cannot compare with the Amazon/Orinoco basins in number of species, its unique geography has led to high rates of endemism. In the last 25 years, the staff of the Museo de Zoología (MZFC) has collected in various geographic areas of Mexico, especially along altitudinal transects in some of the principal physiographic regions in the south and west of the country, as well as by political units (States); see Raguso \& Llorente-Bousquets (1991), Vargas et al. (1994, 1996, 1999), Luis-Martínez et al. (1991, 1996), Warren et al. (1998), and Llorente-Bousquets et al. (2004). In addition, MZFC researchers have examined a dozen collections in the United States and Mexico to form a data base of more than 500,000 specimens (Luis-Martínez et al. 2000, $2003,2005)$. One of the results of these collections and examinations has been the discovery of new taxa in several families of Papilionoidea (see Llorente-Bousquets (1984), Llorente-Bousquets \& Luis-Martínez (1988, 1992), Llorente-Bousquets et al. (1993 a,b)).

In this paper, four new taxa of the family Riodinidae are described. Two of these belong to the genus Euselasia Hubner, 1819 and one each in Exoplisia Godman \& Salvin, 1886 and Synargis Hubner, 1819. These add to the lists recently published by Callaghan \& Lamas (2004) and Llorente-Bousquets et al. (2006) of Mexican Riodinidae. This paper is part of a project to catalogue and study the biogeography of Mexican diurnal Lepidoptera (Llorente-Bousquets et al., 2006). 


\section{Material and methods}

The following descriptions are based on specimens from the collection of the Museo de Zoología "Alfonso L. Herrera", Facultad de Ciencias (MZFC), Universidad Nacional Autónoma de México (UNAM), McGuire Center for Lepidoptera and Biodiversity, Florida Museum of Natural History (MGCL), and that of the senior author (CJC). Voucher specimens are in the collections of the UNAM and CJC, and the types in the UNAM.

\section{Descriptions}

\section{Euselasia pontasis sp. nov.}

(Figures 1, 10, 15)

Description. Male. Forewing length of Holotype $15 \mathrm{~mm}$. Forewing costa curved, tip slightly falcate, distal margin straight to $\mathrm{Cu}_{1}$, where it angles sharply to the pointed tornus. Hind wing costa short, curving concave to a point at $\mathrm{Cu}_{1}$, then again bending concave to a point at the tornus; inner margin nearly straight to base. Dorsal wing ground color dark brown. Forewing with dark orange area extending from cell to inner margin; hind wing with round dark orange discal area below cell, inner margin dark grey. Ventral surface ground color grey - brown. Forewing with a row of submarginal spots between veins, and a faint irregular band crossing the discal area from costa to inner margin; hindwing with similar row of sub-marginal spots; discal area lighter with paler scaling extending along veins into limbal area; the indistinct discal band, continuing from the forewing, extends from costa to end of the cell where it divides slightly before rejoining, continuing to just before inner margin where it curves abruptly basad.

Head, thorax, abdomen dark orange dorsad, dark brown ventrad; antennae brown, ventrad with white scales between sections; orbit, frontoclypeus; labial palpi and forelegs dark brown; median and hind legs cream colored.

Male genitalia (Fig.11) with uncus same length as tegumen, squared with minute teeth, and with a small dorsal notch; tegumen rounded caudad with long blunt lateral projections nearly reaching the valvae; vinculum narrow, slightly wider at base. Valvae pointed, narrow, rounded at base with long, thick lateral setae; dorsal process on transtilla prominent and pointed; aedeagus slightly curved, with a rounded point.

Female. unknown

Types. Holotype male with label reading: "Chincultic", Chiapas, 11-VII-92, John Kemner 4500', 468 KEMNER 2870 Base Kemner, and a red type label. 5 Paratype males as follows: 2 males Santa Rosa Comitán, Chiapas, V-61, leg. Escalante, MGCL/4110, 4111; 1 male Ochna, [Ochuc] Chiapas, 17-X-65. leg. P. Hubbell, MGCL/4112; 1 male Las Delicias, Chiapas, leg. R. Wind MGCL/4102; 1 male S. Cristóbal de las Casas 4800'25-VI-69, leg. R. Wind, MGCL/4113.

The Holotype is deposited in the MZFC. The paratypes are in the McGuire Center for Lepidoptera and Biodiversity, Florida Museum of Natural History.

Etymology. The name refers to the pointed distal margins on the fore- and hind wings.

Diagnosis. This little butterfly appears at first glance to be related to Euselasia angulata (Bates, 1868), sharing the pointed distal margins on both fore- and hindwings. Examination of the male genitalia of both species, however, shows many differences between them. Euselasia pontasis has a longer process on the tegumen, lacks internal process on the valvae and has a narrower aedeagus. The male genitalia are not close to any other Mexican riodinid.

Distribution and Habits. (Fig. 15) This species inhabits the southern highlands in the State of Chiapas near the Guatemalan border. Nothing is known of its habits. The holotype comes from Chinkultic (an archeological site of the Mayan culture in the Parque Nacional Lagunas de Montebello, La Trinitaria Municipality in Chiapas; $\left.16^{\circ} 36^{\prime} 50^{\prime \prime} 91^{\circ} 47^{\prime} 30^{\prime \prime}\right)$. This species probably also occurs in Guatemala highlands. 


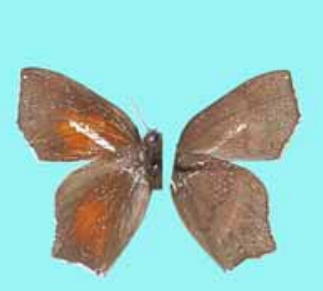

1

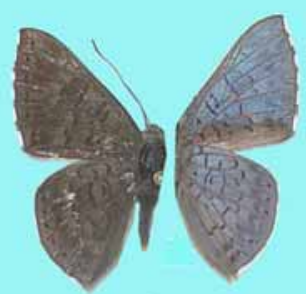

2

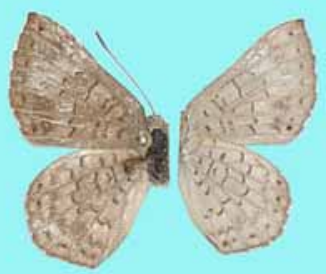

3

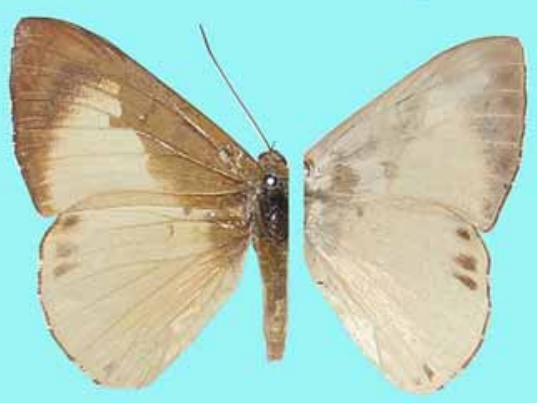

4

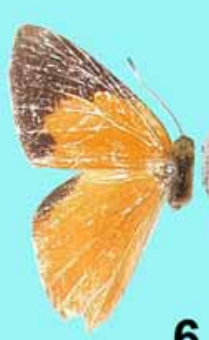

6

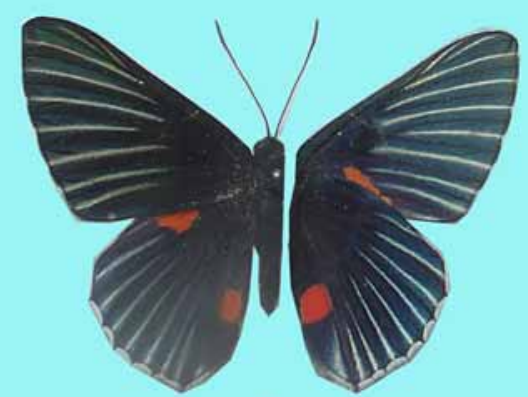

8

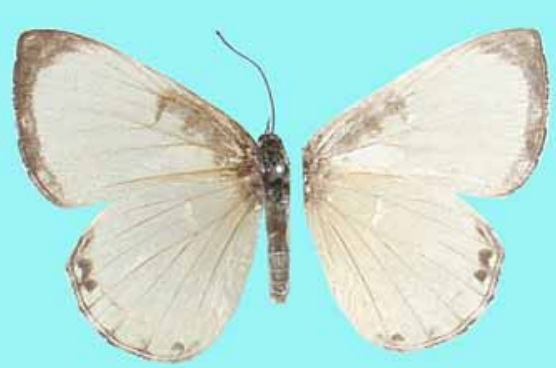

5

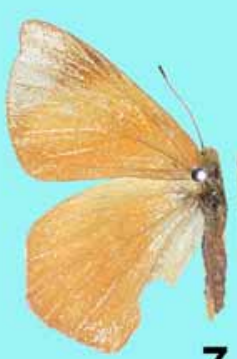

7

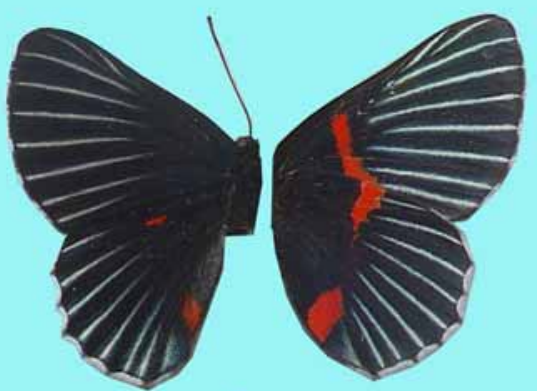

9

FIGURES1-9. 1.Euselasia pontasis, sp. nov., male Holotype. Chincultic, Chiapas, México. 2.Exoplisia azuleja sp. nov., male Holotype. La Calera, Casimiro Castillo, Jalisco, México. 3.Exoplisia azuleja sp. nov., female. 4.Synargis nymphidioides septentrionalis, ssp. nov. male Holotype. Popoctépetl, Veracruz, México. 5.Synargis nymphidioides septentrionalis, ssp. nov. female. 6.Euselasia aurantiaca aurum, ssp. nov., male Holotype. Cueva del Borrego, Omiltemi, Chilpancingo de los Bravos, Guerrero, México. 7.Euselasia aurantiaca aurum, ssp. nov., female. 8.Necyria larunda, reinst. Status, male. 9.Necyria larunda, reinst. Status, female. 

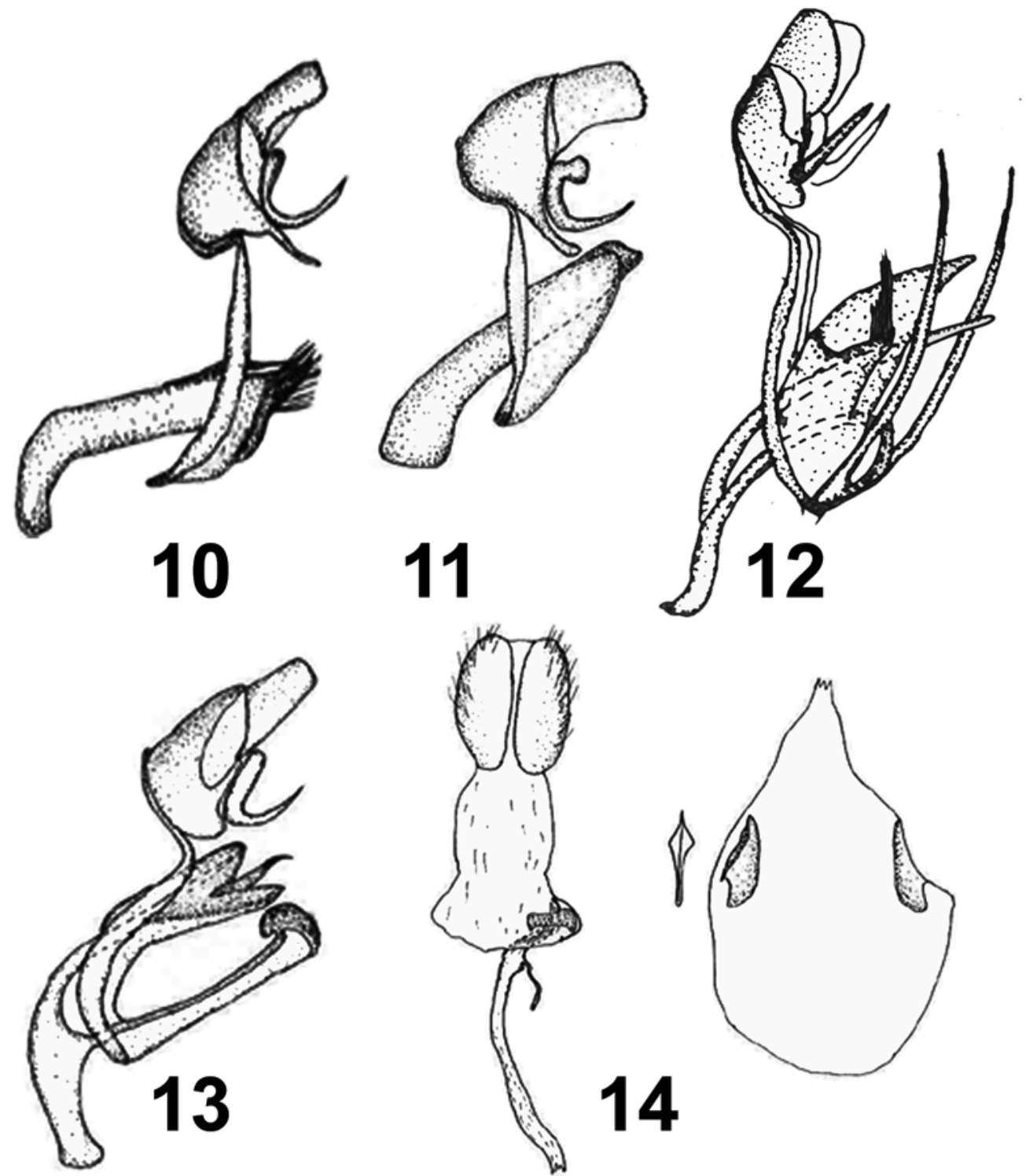

11
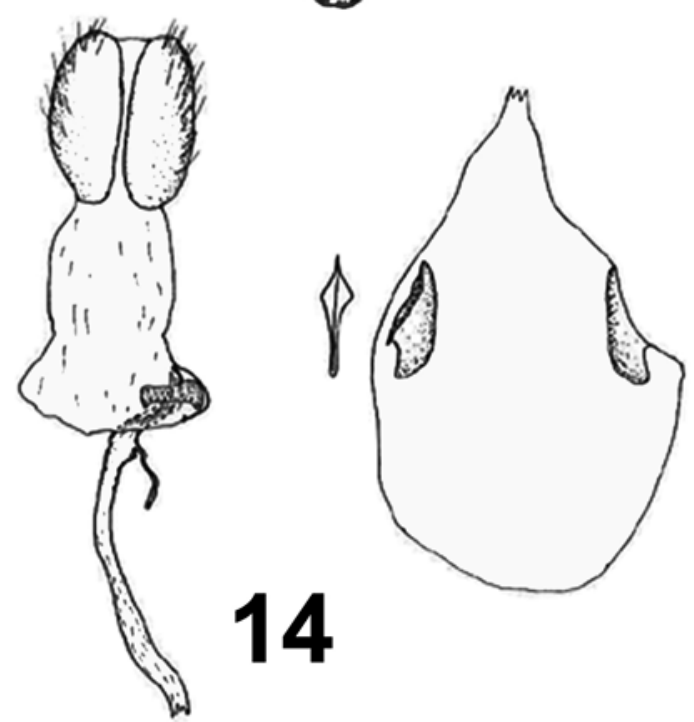

FIGURES 10-14. 10.Euselasia pontasis, sp. nov., male genitalia. 11.Euselasia aurantiacus aurum, sp. nov., male genitalia. 12.Necyria larunda, reinst. Status, male genitalia. 13.Exoplisia azuleja sp. nov., male genitalia. 14.Exoplisia azuleja sp. nov., female genitalia.

\section{Euselasia auriantiaca aurum ssp. nov.}

Figures 6, 7, 11, 15

Description. Male. (Fig. 6) Forewing length of Holotype $18.5 \mathrm{~mm}$. Forewing costa slightly curved, distal margin slightly convex, inner margin straight; hind wing costa curved, distal margin straight and elongated, tornus rounded. Dorsal wing ground color dark yellow-orange with black markings. Apex and distal margin of forewing broadly black, starting from $1 / 3$ of the way along the costa, then across the end of cell, nearly to the tornus where it turns slightly basad. Apex of hindwing black. Ventral surface ground color uniform light yellow-grey, slightly darker where upper surface is dark brown, with a row of faint sub-marginal spots between the veins on both wings and an irregular, narrow, light brown discal band, continuing straight across both wings nearly to inner margin of hindwing where it jags basad. Head, thorax, abdomen brown dorsad, white ventrad; antennae brown, ventrad with white scales between sections, more extensive near flattened clubs; 
orbit, frontoclypeus, labial palpi and legs white. Genitalia (Fig.11) with uncus projecting caudad at base to a point, 34 small caudad projecting teeth on each side; tegumen with long basal projection and a dark irregular sclerotized patch dorsad; falces wide with end closest to uncus bent. Vinculum long with a slight widening in center and slightly wider at base. Valvae short, squared and double pointed on the tips which are curved inward and more heavily sclerotized at base; transtilla with long, pointed process dorsad; aedeagus short, thick.

Female (Fig. 7) Forewing length $21.3 \mathrm{~mm}$. Forewing slightly convex, broadly falcate at apex, distal margin rounded, hind wing distal margin rounded with a sharp angle at $\mathbf{M}_{3}$. Ground color light yellow orange, apex forewing light brown, continuing down margin to tornus. Ventral surface light brown with a row of marginal spots between the veins and a light irregular discal band across both wings.

Types. Holotype male with label reading: Cueva del Borrego, Omiltemi, Chilpancingo de los Bravos, Guerrero, 2-II-1985, J. Llorente, B. de Encino 1850 m. 10:55h, and a red type label. Paratypes 22 males, and 19 females: NAYARIT: Venustiano Carranza, Tepic, 24-XI-1980, 20-IV-1988, J. Llorente 1150 m; MICHOACÁN: Jicalán, Uruapan, L. González Cota, 1640 m on following dates: 19-X-1990, 25-X-1990, 01-XII1990, 02-XII-1990, 06-II-1991, 15-II-1991, 19-II-1991, 20-II-1991, 21-II-1991, 22-II-1991, 15-XI-1991, 16XI-1991, 15-II-1992. JALISCO: Los Mazos, Autlán, 12-XI-1990, I. Vargas, 1750 m. GUERRERO: Cueva del Borrego, Chilpancingo de los Bravos, 2-II-1985, J. Llorente; 3-V-1985; A. Luis, $1850 \mathrm{~m}$; Potrerillo, Omiltemi, Chilpancingo de los Bravos, 2300 m, 09-VI-1985, J. Llorente-A. Luis; Laguna de Agua Escondida, Omiltemi, Chilpancingo de los Bravos, 2350 m; 21-XI-1984, J. Llorente-A. Luis.

Other material examined: 36 males, and 7 females: NAYARIT: Venustiano Carranza, Tepic, $1060 \mathrm{~m}$, 04-XII-1979; E. González, 1060 m. MICHOACÁN: Jicalán, Uruapan, L. González Cota, 1640 m, on the following dates: 05-II-1990, 19-X-1990, 20-X-1990, 24-XI-1990, 24-XI-1990, 25-X-1990, 30-XI-1990, 06-II1991, 11-II-1991, 13-II-1991, 14-II-1991, 15-II-1991, 18-II-1991, 19-II-1991, 20-II-1991, 21-II-1991, 22-II1991, 28-II-1991, 19-X-1991, 20-X-1991, 25-X-1991; Cerro de la Cruz, Uruapan, 23-IX-1989; González Cota, $2200 \mathrm{~m}$.

The Holotype and paratypes are deposited in the MZFC.

Etymology. The name refers to the golden-yellow ground color of the upperside of the wings.

Diagnosis. The maculation of Euselasia auriantiaca aurum resembles that of Euselasia auriantiaca aurantiaca (Salvin \& Godman, 1868), which also occurs in southern México (Veracruz), but the male of E. $a$. aurum has more truncated hind wings and the dorsal ground color is pale yellow instead of orange-yellow. Ventrally, the nominate subspecies is white instead of light yellow and more strongly marked with a wide discal band. The male genitalia of E. a. aurantiaca are similar to those of E. a. aurum in having a similar uncus and equally sclerotized tegumen; however the basal projection of the tegumen is squared instead of pointed. The valvae are slightly longer in E. a. aurantiaca than in E. a. aurum, and the tips are more deeply bisected. More data from northern Oaxaca is needed on these two phenotypes to determine whether they are truly conspecific. For now, we conservatively treat them as subspecies.

Distribution and Habits. Euselasia a. aurum inhabits the Pacific slope of Mexico from central Oaxaca north to Nayarit. It is found in a great variety of habitats from 900 to $2400 \mathrm{~m}$, from the most humid cloud forest to dryer habitats such as semi evergreen forest, dry tropical forest, oak forest (Quercus) and pine-oak forest (Pinus-Quercus). It is found of perching along forested edges in the early afternoon, often in the company of Adelpha species. Euselasia aurantiaca aurantiaca ranges from Venezuela and Central America north to Chiapas and Veracruz on the Mexican Atlantic slope.

\section{Necyria larunda Godman \& Salvin, 1885, Reinstated Status}

Figures 8, 9, 12, 15

Biol C. Americana. Insecta Lepidoptera-Rhopalocera. p. 397, pl. 43 figs. 11,12.

Necyria larunda was described and illustrated from a male in poor condition received by Godman and Salvin 
in a box of material from Guatemala. Later publications referred only to the original description. The next record of this species was a male specimen from Santa Rosa, Municipality Las Margaritas, Chiapas cited and illustrated by J. \& R. de la Maza (1980). In the Atlas of Neotropical Lepidoptera-Checklist, Callaghan and Lamas (2004) placed this taxon as a subspecies of $N$. duellona Westwood, 1851. The discovery of a short series of $N$. larunda in the collection of the McGuire Center for Lepidoptera and Biodiversity, University of Florida (Gainsville), from the Escalante collection, provided the senior author with the opportunity to examine the genitalia of this species and compare it with other Necyria taxa. The result suggests that $N$. larunda is indeed distinct and should be maintained as a species-level taxon.

Diagnosis. Male (Fig. 8): Dorsal wing ground color black, crossed by long white lines from margin to discal area between the veins; hind wing with two red spots, one on the costa above the cell and the other at the inner margin; ventral surface same with red spots on inner margins of both wings. Genitalia (fig. 12): Uncus slightly bifurcated, tegument straight with slight extension basad; vinculum narrow, curved in the middle, joining at a small saccus; valvae in form of two long narrow processes with long, thick setae on tip; transtilla long, pointed with two lateral processes tipped with long setae extending vertically. Aedeagus long, narrow. Female (Fig. 9) Dorsad identical to male; ventrad with a variable elongated red band crossing discal area, continuing to costa of hind wing; elongated red spot on inner margin. Genitalia with ostium bursae wide, platelike with slit in center leading to ductus bursae; signae small, flattened.

Discussion. Necyria larunda differs from $N$. duellona beltiana from Nicaragua and Costa Rica in the absence of the bright blue distal markings on the ventral surface and the elongated white lines between the veins (see DeVries, 1997). The male genitalia of $N$. duellona have much shorter valvae; the lateral processes on transtilla are curved dorsad and transtilla is beaked; the vinculum is straight. These differences, as well as the lack of any intermediate material, suggest that $N$. larunda is a species-level taxon.

Range: (Fig. 15) Known only from Chiapas State, Mexico and "Guatemala".

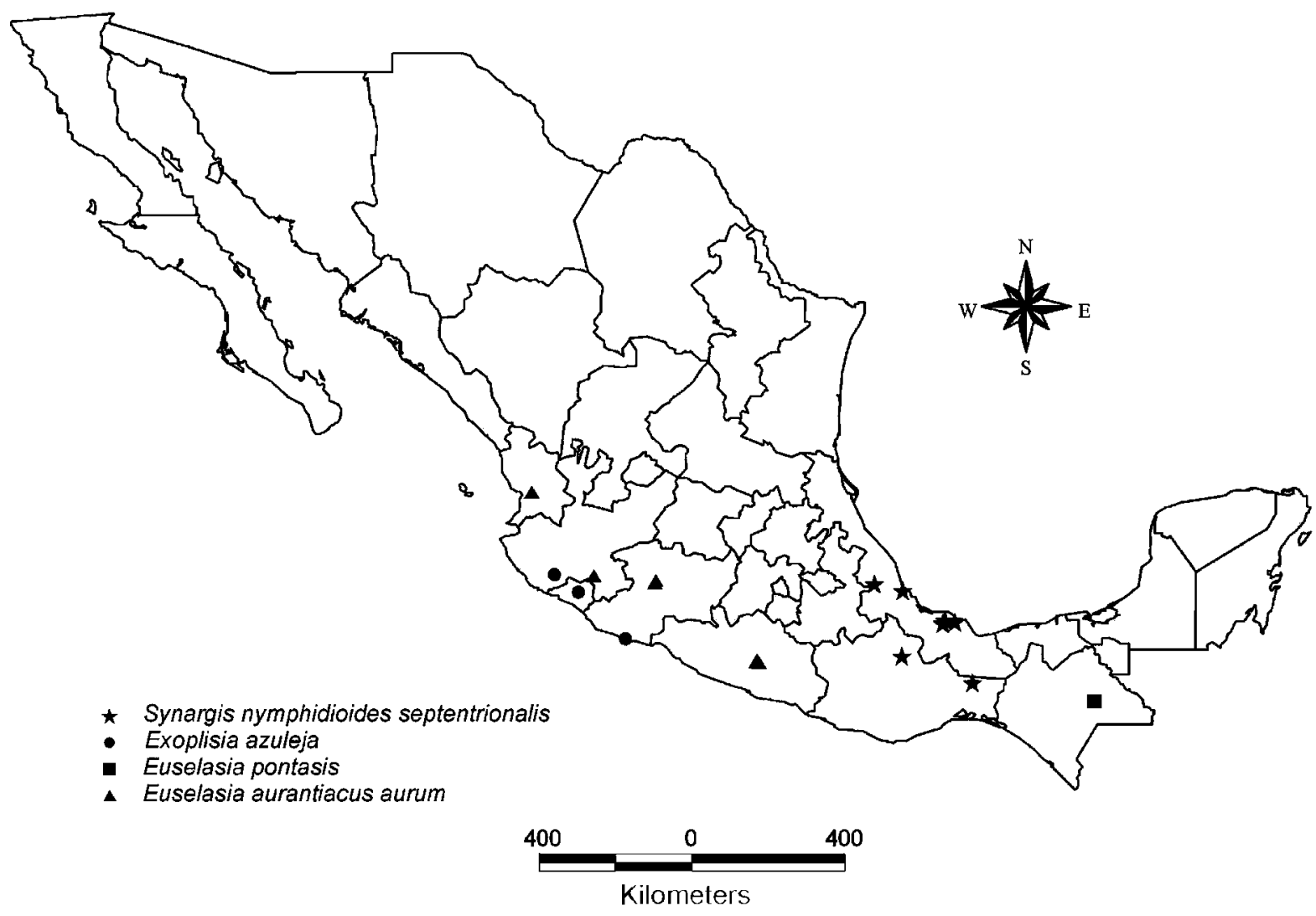

FIGURE 15. Distribution map of new taxa. 
Material examined. 3 males and 3 females from Santa Rosa Comitán, Chiapas, in MGCL, leg. T. Escalante.

\section{Exoplisia azuleja sp. nov.}

Figures 2, 3, 13, 15

Description. Male. (Fig. 2) Forewing length of Holotype $16.0 \mathrm{~mm}$. Forewing costa straight, slightly curved at apex which is slightly falcate, distal margin slightly convex, inner margin straight; hindwing apex rounded, distal margin curves to a point at anal angle; inner margin with long scales. Dorsal wing ground color dark blue-grey. Discal cell of forewing with four short black lines, which continue below cell slightly offset to 2A, three small, faint elongated marks past the end of the cell, in cells $\mathrm{Cu}_{1}-\mathrm{Cu}_{2}, \mathrm{Cu}_{2}-\mathrm{Cu}_{3}$, and $\mathrm{Cu}_{3}-\mathrm{M}_{1}$; a sub-marginal row of faint black marks between the veins alternating with a short silver line at the end of each vein, and bordered basad by an irregular patch of dark scaling. Fringe white interspersed with black marks at end of veins. Hindwing with black line at end of discal cell, and an additional line and two internal spots which continue offset in the cells above and below; distad of these a limbal row of unconnected indistinct short black lines between costa and inner margin; a submarginal row of black spots alternating with silver marks on the veins and each marked basad with a small crescent; fringe solid white. Ventral surface ground color blue-grey with a metallic gloss. Forewing dark grey below $\mathrm{M}_{3}$, inner margin lighter, hindwing with discal area lighter than sub margin. Both wings with black marks reflecting dorsal maculation.

Head, thorax, abdomen dark blue-grey dorsad, ventrad pubescent, tip of abdomen with yellow scales around terminalia; antennae brown, ventrad with white scales between sections; orbit, frontoclypeus, labial palpi blue-grey, forelegs very pubescent, other legs with coxa pubescent. Genitalia (Fig. 13) with uncus straight across tip, tegumen deeply notched cephalad; vinculum thin, uniform, strongly curved not fused to tegumen, valvae flat with rounded tips, transtilla high, peaked with two pointed caudad processes; aedeagus thin, attached to long projection of pedicel with fully developed scobinate patch on the tip.

Female. (Fig. 3) Forewing length of specimen measured $14.3 \mathrm{~mm}$. Ground color dorsal forewing light grey-brown, maculation as on male, marginal silver lines on veins reduced. Ventral surface lighter. Head, thorax, abdomen dorsally brown, ventrad with white - light brown scaling. Genitalia (Fig. 14). Ostium bursae with an irregular highly sclerotized, asymmetrical ventral plate, ductus seminalis exits at base of ostium bursae; ductus bursae bent to left when viewed ventrally; invaginated signae in corpus bursae large, rounded.

Types. Holotype male with label reading: La Calera, Casimiro Castillo; Jalisco 600 m 13-xi-1990 I. Vargas MZFC-80565, and a red type label reading "Exoplisia azuleja". Paratypes: 62 males and 31 females: Male: 1 same locality data as Holotype, 24-IV-1989, MZFC-74974, A. Luis-V. Bedoy BTS; 50 males: La Calera, Casimiro Castillo 650 m 12-III-1996 A. Luis-J.L. Salinas; 650 m, BTS y s/húmeda; females: A. Luis-V. Bedoy (1) 24-IV-1989 500-600, (3) J. Llorente-A. Luis 15-IX-1990 600, (4) J. Llorente-A. Luis 13-XI-1990; (1) J. Llorente 13-XI-1990; (1) I. Vargas 13-XI-1990; (3) A. Luis 13-XI-1990; (4) J. Llorente-A. Luis 14-XI1990; (1) I. Vargas 15-XI-1990; (4) A. Luis-J.L. Salinas 12-III-1996; (7) A. Luis-J.L. Salinas 14-III-1996 todos en 650 m, BTS y s/húmeda; (1) J. Llorente-A. Luis 15-IX-1990 600 s/flor, A. Luis 22-VI-1991 650 s/ flor; MICHOACÁN: 10 males; Caleta de Campo, Lázaro Cárdenas; L. González Cota; 12-III-1996; 30 m; s/ húmeda; COLIMA: 2 males; El Salto; I. Vargas; 3-I-1996; BTC; MZFC-58243; Punta de Agua de Camatlán, 2 km NE, I. Vargas, 1-I-1996, BTC, MZFC-58297, 1 female MZFC-58247.

The Holotype and paratypes are deposited in the MZFC.

Other material examined: 267 males: JALISCO: La Calera, Casimiro Castillo 600-650 m, BTS: (22) A. Luis-V. Bedoy 24-IV-1989; (6) J. Llorente-A. Luis 22-VIII-1990; (1) I. Vargas 15-IX-1990; (7) A. Luis 15IX-1990; (6) I. Vargas 13-XI-1990; (10) A. Luis 13-XI-1990; (4) A. Luis 14-XI-1990; (4) J. Llorente 14-XI1990; (4) I. Vargas 14-XI-1990; (8) A. Luis 14-XI-1990; (4) I. Vargas 15-XI-1990; (5) A. Luis 15-XI-1990; 
(1) A. Luis 22-VI-1991; (1) A. Luis 16-XI-1992; (3) A. Luis 16-XI-1992; (120) A. Luis-J.L. Salinas 12-III1996; (62) A. Luis-J.L. Salinas 14-III-1996.

Etymology. The name refers to the grey-blue ventral surface of the wings.

Diagnosis. This species is closest to Exoplisia cadmeis (Hewitson) from western South America, with the same general pattern of wing maculation. However, E. cadmeis is larger, darker dorsally with heavier markings and the male lacks the orange scales on the tip of the abdomen. The ventral wing surface of E. cadmeis males has a brighter blue reflection and heavier maculation. The male genitalia of the two species are similar in form. However, in E cadmeis, the scobinate patch is folded over caudad, instead of rounded, and the pedicel is much longer extending well beyond the tips of the valvae. The female of $E$. cadmeis has a more prominent row of marginal spots and heavier maculation. The female genitalia of E. cadmeis, likewise, has the irregular sclerotized ventral flange on the ostium bursae, but this is rounder and the beginning of the ductus bursae is not as strongly sclerotized as in E. azuleja.

It is odd that this prominent and common butterfly was not described previously. Perhaps this is due to its inhabiting the west of the country where not as much collecting has been done (Vargas et al., 1998, 1999; Warren et al., 1998).

Distribution and Habits. This species is found in medium height forest in Michoacán, Jalisco and Colima, in humid riverine areas during the late afternoon. Both males and females are commonly encountered drinking at wet sand with wings outspread, similar to males of other riodinids, i.e., Rhetus Swainson, 1829 and Lasaia Bates, 1868. The difference is that adults of E. azuleja prefer areas shaded by trees and bushes, rather than in direct sunlight. They are rarely observed in open areas or during the hottest hours of the day.

\section{Synargis nymphidioides septentrionalis ssp. nov.}

(Figures 4, 5, 15)

Description. Male (Fig. 4). Forewing length of Holotype $26.2 \mathrm{~mm}$, material examined between 24 and $28 \mathrm{~mm}$ $(n=6)$. Wing ground color cream; forewing costa and distal margins reddish brown, discal area cream colored, triangular shaped, the distal side curving to the tornus, and the basal side forming a ragged edge extending distad of the discal cell to inner margin, with a small intrusion of reddish brown scaling into cell $\mathrm{M}_{3-} \mathrm{Cu}_{1}$. Hindwing cream colored except for reddish brown base, three submarginal spots above and below $\mathrm{M}_{1}$ and in cell $\mathrm{M}_{1-} \mathrm{M}_{2}$, with 2 fainter similar markings at tornus. Fringe dark brown on both wings. Ventral wing ground color cream with dorsal pattern appearing through; marginal spots on hind wings darker. Genitalia as in nominate subspecies. Palpi short, barely appearing in front of the face when viewed dorsally.

Female (Fig. 5). Forewing length $25 \mathrm{~mm}$. Ground color dirty white; forewing margin dark brown curving to tornus, costa from middle of cell to base dark brown. Hindwing white with a black marginal line from apex to tornus, basad three small black spots on the apex and two at the tornus; basad of this a faint dark brown line; fringe variable dark brown and white. Ventral surface white, reflecting dorsal pattern. Palpi long, nearly 3 times that of male.

Types. Holotype male with label: González Cota, Popoctépetl; Veracruz, 15-VI-83 MZFC-42365. Paratypes: 10 Males and 12 females. VERACRUZ: Santiago Tuxtla, VII-1975 T. Escalante MZFC-3071; Dos Amates, VII-1973 T. Escalante MZFC-3072; El Vigía, 16-VIII-1982 L. González Cota MZFC-42366; same locality, IV-1969 (CJC); Tapalapan, L. González Cota 20-VII-1982 MZFC-42360; 5-VIII-1982 MZFC42364; 8-VIII-1982 MZFC-42361; 12-VIII-1982 MZFC-42362;14-VIII-1982 MZFC-42363; 25-VIII-1982 MZFC-3074; females: Barranca de Cayoapa, Tejería, 6-V-1981 Bosque Mesófilo de Montaña- Selva Mediana, 650 msnm, 12:09 H MZFC-3076; Teocelo, Tejería, 6-V-1978 J. Llorente MZFC-42376; Popoctépetl (3) 27-VII-1982 MZFC-3075; MZFC-42370, MZFC-42367, 10-VIII-1980 MZFC-42368; VII-1981 MZFC42369, L. González Cota; Tapalapan L. González Cota 12-VII-1981 MZFC-42373 L. González Cota; El Vigía 
20-VII-1984 MZFC-42371; 24-VIII-1987 MZFC-4029 L. González Cota; OAXACA: Puerto Eligio, Santiago Comaltepec 600 m, 12-VIII-1986 A. Luis-J. Llorente MZFC-3073; females: Chalchijapa, Santa María Chimalapa 27-III-1995 MZFC-42375; 31-V-1995 MZFC-42374 J.L. Salinas-M.O. Vences, Bosque Tropical Perennifolio.

The Holotype and paratypes are deposited in the MZFC.

Etymology. The name refers to the northern latitudes where this taxon is found, relative to the nominate subspecies.

Diagnosis: Males of Synargis nymphidioides septentrionalis are easily separated from the nominate subspecies in having a wide yellow triangular area on the forewing instead of a solid brown color with three white spots. The hindwing pattern differs in the less extensive light brown basal area. The female differs in having lighter, less extensive marginal markings.

Distribution and Habits: This subspecies is found from southern Oaxaca on the border with Chiapas to central Veracruz, in very humid areas with up to $2500 \mathrm{~mm}$ of precipitation (Chalchijapa, Tapalapan and Popoctépetl). It inhabits principally evergreen tropical forest from sea-level to $250 \mathrm{~m}$, but records exist from cloud forests at $900 \mathrm{~m}$ and the transition between this and semi-evergreen forest at $650 \mathrm{~m}$. The nominate subspecies in Costa Rica occurs on the western Pacific slope from sea-level to $1000 \mathrm{~m}$. (DeVries, 1997), and reaches Mexico in Chiapas (El Aguacero, Ocozocuala, Bonampak, Chajul, in de la Maza, 1987). The habitat of $S$. $n$. nymphidioides in Chiapas is dry forest, which contrasts with the wet habitat of $S$. $n$. septentrionalis. This taxon is rare, generally encountered in the best preserved areas of the habitat, and appears to be an endemic Mexican butterfly.

The biology of the species is unkown, although DeVries (1997) recorded the nominate subspecies associated with ants and Acacia trees in Guanacaste, Costa Rica.

\section{Discussion}

During the last three decades, the discovery and description of an ever greater number of taxa from Mexico have come from cloud forest habitats. This is the case with the two Euselasia described here. However, in the last few years, the exploration of dry habitats, especially on the Pacific coast, has supplied additional material unknown to science. Examples of this are Voltinia danforthi (A. Warren \& Opler, 1999) and Exoplisia azuleja. However, both of these species are found in humid microhabitats within deciduous and subperennial tropical forest, surrounded by xeric habitats (see Austin et al., 2007, to new Opsiphanes).

Despite the extensive exploration of the Mexican Pacific coast during the 1980's (Vargas et al., 1996, 1999; Warren et al., 1998; Llorente-Bousquets et al., 2004), there remain many areas to investigate in which new taxa are likely to be found. For example, in some well explored areas, lepidopterists have discovered new species or extended the distribution of species that were not thought to occur on the Mexican Pacific slope (Luis-Martínez et al., 1992; Llorente-Bousquets et al., 1993b; Vargas et al., 1994, 1996, 1999).

An example was the discovery by John Kemner, Armando Luis and Jorge Llorente of Lieinix neblina J. \& R. G. Maza 1984 (Pieridae) in several places in Oaxaca, when it was thought to be endemic and limited to the Sierra de Atoyac in Guerrero State (Vargas et al., 1994). The highly fragmented nature of the cloud forest habitats on the Mexican Pacific slope (Llorente-Bousquets, 1984; Llorente-Bousquets y Escalante, 1994), in accordance with the discoveries reported in this article, should be explored in each of its diverse biological habitats with greater effort, for it is quite possible to find undescribed taxa or increase the known distributions of species and subspecies which are believed to be restricted to the places where they were originally discovered. 


\section{Acknowledgements}

The authors wish to thank Dr. J. Miller for loan of material from the McGuire Center for Lepidoptera and Biodiversity, Florida Museum of Natural History, Gainesville, Florida. The grant of UNAM, PAPIIT IN212006 was very important to the authors. Thanks to Isabel Vargas Fernández for helping in the collection of specimens. Special thanks to Andrew Warren for critiques and suggestions. To Marysol Trujano for the map.

\section{References}

Austin, G. T., Warren, A. D., Penz, C. M., Llorente-Bousquets, J., Luis-Martínez, A. \& Vargas, I. F. 2007. A new species of Opsiphanes Doubleday, [1849] from western Mexico (Nymphalidae: Morphinae: Brassolini). Bulletin of the Allyn Museum, 150: 20 pp.

Callaghan, C.J. \& Lamas, G. (2004) Riodinidae. In: Lamas, G. (Ed.), Checklist: Part 4A. Hesperioidea-Papilionoidea. Atlas of Neotropical Lepidoptera. Association for Tropical Lepidoptera. Scientific Publishers, Gainesville, 439 pp.

DeVries, P. (1997) The butterflies of Costa Rica and their Natural History II. Riodinidae. Princeton University Press. 288 pp.

Godman, F. \& Salvin, O. (1885) Biologia Central-Americana. Insecta. Lepidoptera-Rhopalocera. Dulau \& Co., Bernard Quaritch, London. 1, 361-400.

Llorente-Bousquets, J. (1984) Sinopsis sistemática y biogeográfica de los Dismorphiinae de México con especial referencia del género Enantia Huebner (Lepidoptera: Pieridae). Folia entomológica Mexicana, 58, 1-207.

Llorente-Bousquets, J., Descimon, H. \& Johnson, K. (1993a) Taxonomy and biogeography of Archaeoprepona demophoon in Mexico with description of a new subspecies (Nymphalidae: Charaxinae). Tropical Lepidoptera, 4 (1), $31-36$.

Llorente-Bousquets, J. \& Luis-Martínez, A. (1988) Nuevos Dismorphiini de México y Guatemala (Lepidoptera: Pieridae). Folia entomológica Mexicana, 74, 159-178.

Llorente-Bousquets, J. \& Luis-Martínez, A. (1992) Distribución de Consul electra (Westwood) y una nueva subespecie de México (Nymphalidae: Charaxinae; Anaeini). Anales del Instituto de Biología de la UNAM, Serie Zoología, 63 (2), 237-247.

Llorente-Bousquets, J. \& Luis-Martínez, A. (1993) A conservation-oriented analysis of Mexican butterflies: the Papilionidae (Lepidoptera: Papilionoidea). In: Ramammorthy, T.P., Fa, J., Bye, R. \& Lot, A. (Eds), The biological diversity of Mexico: origins and distributions. Oxford University Press, pp. 147-177.

Llorente-Bousquets, J., Luis-Martínez, A. \& González, L. (1993b) Diferenciación de Prepona deiphile en Mesoamérica y descripción de dos subespecies nuevas. Tropical Lepidoptera, 3(2), 109-114.

Llorente-Bousquets, J. \& Escalante, P. (1994) Insular biogeography of submontane humid forest in Mexico. In: Darwin, S. P. \& Welden, A. L. (Eds), Biogeography of Mesoamerica. University of Louisiana, pp. 139-146.

Llorente-Bousquets, J., Luis-Martínez, A. \& Vargas, I.F. (2006) Apéndice general de Papilionoidea: Lista sistemática, distribución estatal y provincias biogeográficas. In: Morrone, J.J. \& Llorente-Bousquets, J. (Eds.), Componentes bióticos principales de la entomofauna mexicana, Vol. II. Las Prensas de Ciencias, Fac. Ciencias, UNAM, México, D. F. pp. $945-1009$.

Llorente-Bousquets, J., Luis-Martínez, A., Vargas, I.F. \& Warren, A.D. (2004) Butterflies of the state of Nayarit, Mexico. Journal of the Lepidopterists' Society, 58(4), 203-222.

Luis-Martínez, A., Vargas, I.F. \& Llorente-Bousquets, J. (1991) Lepidopterofauna de Oaxaca I. Distribución y Fenología de los Papilionoidea de la Sierra de Juárez. Publicaciones especiales del Museo de Zoología, UNAM, 3, 1-121.

Luis-Martínez, A., Llorente-Bousquets, J. \& Vargas, I.F. (1992) Redescubrimiento de Paramacera copiosa en la Sierra Madre del Sur, Guerrero, Mexico (Lepidoptera: Nymphalidae; Satyrinae). Tropical Lepidoptera, 3(2), 115 - 117.

Luis-Martínez, A., Vargas, I.F. \& Llorente-Bousquets, J. (1996) Síntesis de los Papilionoidea (Lepidoptera: Rhopalocera) del estado de Veracruz. Folia entomológica Mexicana, 93, 91-133.

Luis-Martínez, A., Llorente-Bousquets, J., Vargas, I.F. \& Gutiérrez, A.L. (2000) Síntesis preliminar del conocimiento de los Papilionoidea (Lepidoptera: Insecta) de México. In: Martin, F., Morrone, J.J. \& Melic, A. (Eds.), Monografías Tercer Milenio (Boletín Sociedad Entomológica Aragonesa), 1, 275-285.

Luis-Martínez, A., Llorente-Bousquets, J., Vargas, I.F. \& Warren, A.D. (2003) Biodiversity and biogeography of Mexican butterflies (Lepidoptera: Papilionoidea and Hesperioidea). Proceedings of Entomological Society of Washington, 105(1), 209-224.

Luis-Martínez, A., Llorente-Bousquets, J. \& Vargas, I.F. (2005) Una megabase de datos de mariposas de México y la regionalización biogeográfica. En: Llorente-Bousquets, J. \& Morrone, J.J. (Eds.), Regionalización biogeográfica en Iberoamérica y tópicos afines. Primeras Jornadas Biogeográficas RIBES. Las Prensas Ciencias, Fac. Ciencias, 
UNAM. México, D.F. pp. 269-294.

Maza de la, J. \& Maza, R. de la (1980) Notas y descripciones sobre la familia Riodinidae en Mexico. Revista de la Sociedad Mexicana de Lepidopterología, 6(1), 7-19.

Maza de la, R. (1987) Mariposas Mexicanas. Fondo de Cultura Económica, México, D.F., 300 pp.

Raguso, R.A. \& Llorente-Bousquets, J. (1991) The butterflies (Lepidoptera) of the Tuxtlas Mts., Veracruz, Mexico, revisited: Species-richness and habitat disturbance. Journal of Research on the Lepidoptera, 29(1-2), $105-133$.

Vargas, I.F., Llorente-Bousquets, J. \& Luis-Martínez, A. (1994) Listado lepidopterofaunístico de la Sierra de Atoyac de Álvarez en el estado de Guerrero: notas acerca de su distribución local y estacional (Rhopalocera: Papilionoidea). Folia entomológica Mexicana, 86, 41-178.

Vargas, I.F., Llorente-Bousquets, J. \& Luis-Martínez, A. (1999) Distribución de los Papilionoidea (Lepidoptera: Rhopalocera) de la Sierra de Manantlán (250-1650 m) en los estados de Jalisco y Colima. Publicaciones especiales del Museo de Zoología, UNAM, 11, 1-153.

Vargas, I.F., Luis-Martínez, A., Llorente-Bousquets J. \& Warren, A.D. (1996) Butterflies of the state of Jalisco, Mexico. Journal of the Lepidopterists' Society, 50(2), 97-138. List alphabetically, before Warren.

Warren, A.D., Vargas, I.F., Luis-Martínez, A. \& Llorente-Bousquets, J. (1998) Butterflies of the state of Colima, Mexico. Journal of the Lepidopterists' Society, 52(1), 40-72. 
